\title{
Criteria for Investing in the Market of Visual Arts
}

\author{
Elio Amilcar Farfan Torrelles \\ Faculty of Económic and Social Sciences, Carabobo's University, Valencia, Venezuela
}

\section{Email address:}

eliofarfan@gmail.com

\section{To cite this article:}

Elio Amilcar Farfan Torrelles. Criteria for Investing in the Market of Visual Arts. Science Journal of Business and Management. Vol. 7, No. 6, 2019, pp. 140-149. doi: 10.11648/j.sjbm.20190706.12

Received: December 11, 2018; Accepted: November 1, 2019; Published: December 4, 2019

\begin{abstract}
The market for the visual arts carries out a complex activity, which requires identifying key variables to establish valid investment criteria and obtain reasonable profits. This calls for differentiating the purpose of the purchase as either an investment or a collection. Then, focusing on the work and the artist, the trajectory of iconic and emerging elements is investigated and compared to identify the criteria that the buyer should consider when acquiring a piece of visual art. Accurate parameters are needed to invest considering this economic activity has clearly defined segments. For this reason, the claimed characteristics of the artwork, the artist and the market must be assessed as well as the need for the art piece or the added value that an artwork offers to the market and the reason why a certain amount of money must be paid to obtain it. The aim of the present research is to identify key variables to establish valid investment criteria, taking the case of the contemporary Venezuelan Art Market as basis. To achieve this objective, the documentary research methodology was applied and, in addition, interviews with some market agents were carried out, which revealed the presence of many agents with various interests within the market. As a conclusion, the study revealed that the visual arts market is a complex market, which requires different actors to handle accurate and reliable information when making purchasing or sales decisions.
\end{abstract}

Keywords: Art Market, Artwork (Piece), Artist, Collector, Investor, Profits

\section{Introduction}

The visual arts market is as attractive and complex as any other. It seduces us through two great dimensions: the sensory impression, which refers to the pleasure and enjoyment when contemplating artwork in itself and that other of having peace of mind when obtaining financial returns that could solve future economic problems, typical of daily life. However, financial success is difficult and elusive. It is not easy to combine good taste, time, risk and profits.

The artistic offer further complicates the problem. Trends, proposals, styles, classifications, themes, sizes, authors, ages, life and death, emerging artists and established artists and capital limitations are some of the variables that must be combined to select the investor's "obscure object of desire." An experienced dealer would intuitively realize unknowns, which perhaps, would give the result of the equation "contemporary art and market", "beauty and investment." This article aims to identify many key variables and establish valid investment criteria to obtain reasonable profits through parameters which facilitate the purchase of visual art pieces.
When it concerns a piece of visual art, there are some questions such as the following: which is the purpose of acquiring a specific piece? What to buy? Collecting or investing? Which type of asset to invest in? How to undertake the purchase? When to sell or disinvest (liquidate the investment)? What kinds of risks are assumed when acquiring a piece of art? Is it possible to measure these risks or are there other more profitable markets, other optional markets? Therefore, and due to the importance of this economic activity, an analysis is necessary to update knowledge, both qualitative and quantitative, concerning the behavior of the various agents and the market itself. This enables the investor to recognize feasible business opportunities and take advantage of them. However, as in other markets, it is imperative to take chances trying to minimize the risks by focusing on a specific group of artists and pieces that allow the acquisition of the assets and satisfactory returns on each transaction.

For example, according to Sherman, A. and Morrissey, C. "Painting a portrait" was made in compliance with the norms, standards, and expectations of the genre that are, as per their importance, public. Moreover, these norms and standards 
constitute the criteria for considering it an excellent portrait [1]. This article aims to identify many key variables to establish valid investment criteria to obtain reasonable profits through parameters that facilitate the purchase of visual art pieces. In addition, Artprice mentions that "The collection of artwork requires a general understanding of the market, and a certain knowledge of the nature of supply and demand. First, of course, you have to know where and when to buy, and then you have to keep track of price changes, at least for insurance purposes. Like it or not, collecting art is always a form of investment. Fortunately, it's a very lucrative investment [2]". That is why this article aims to identify determinant variables, so that a valid investment criteria can be established to allow earning reasonable profits through parameters that facilitate the purchase of visual art works. In order to achieve this objective, as far as visual artwork is concerned, the reasons for acquiring a specific piece must be specified or defined from the outset. Whether the aim is to collect or invest, or both, one has to choose the best asset that allows a balance between minimum risk and maximum performance or know the different types of risks assumed when acquiring a work of art. As Artsgain referred: "Each artwork or artistic good will always have a value that can rise or fall depending on market forces. Even so, there is an implicit risk in the investment business itself that depends on the evolution of factors external to investors and ARTSGAIN such as the competitive value of the artist, the evolution of the local and global economy, anomalous situations such as earthquakes or wars, among many others [3]". The previous criteria is reinforced by the Securities and Exchange Commission, (2017) which states: "The global art market, in addition to other type of assets, is influenced over time by the overall strength and stability of the global economy, the financial markets of different countries, geopolitical conditions, and world events. However, the global art market often moves independently and sometimes, counter to, general macroeconomic cycles. Ultimately, we believe that the level of activity and buoyancy of the global art market is most prominently impacted by the collective sentiment of art market participants, as well as the individual circumstances of potential art vendors [4]". Similarly, it is important to establish the timing and circumstances to sell or divest. Moreover, it is necessary to compare the opportunities offered by the art world and other markets because decisions in finance are made with references to other forms and models of investment or business.

\section{Some Preliminary Considerations and Research Methodology}

Often, when analyzing a financial event such as an investment in visual arts, it is useful to have an overview of the origins of the problem and take into consideration difficulties such as the reason for the financial investment, as part of the origin of the problem, thus pointing the way to a solution. This requires defining what wealth is, why we accumulate it, what an investment is and why we invest, since it is entirely pertinent to solving the problem. Humanity has accumulated financial resources through different means in order to use them for its survival. Therefore, there have been wars, invasions, inventions, discoveries, and great trips like Columbus', Magallanes', the trip to the moon, crusades and evangelizations. These accumulated resources constitute what is known now as wealth which will be used to meet future needs.

Furthermore, investing is simply the use of financial resources to acquire any temporary asset, such as home appliances, buildings, vehicles, and public debt bonds, shares of a company, certificates of deposit, savings accounts or pieces of visual art. This is advisable to recover the invested capital once the term is due, regardless of the length of the period, and gain profit according to the risks taken (earnings).

The investor must be willing to disinvest, as it is the goal of the process to obtain the expected profit of the transaction. We can say that every investment has a temporary quality, previously defined or not, but essential to materialize the set objective. As always, to make a profit, it is mandatory to choose between different types of assets and different investment instruments, which will produce different dividends. This requires comparing the various assets and deciding which could be most profitable, less risky and give greater personal satisfaction.

When choosing any investment instrument, for a given time and capital, we must first identify the markets in which we will operate. If it is national we will use bolivars, if international, foreign currency; either way business details include: available capital for the operation, forms of payment, types of assets to be acquired, whether they are perishable or long lasting (due to maturity or due date, tradable or non-tradable, movable or static, utilitarian or artistic, of common or special use.

An asset can be acquired to satisfy personal needs or to sell it later and obtain a financial return. Both decisions assume there will be a profit. The first will be measured in terms of satisfying needs and the second in terms of money. Then, capital, income, risk, internal rate of return, volatility, portfolio diversification, trends, bubbles or hedges are terms that must be identified in the development of this particular form of investment, which is not always easy, due to how complex and segmented this economic activity is. This is an important part of the challenge of making the decision to invest, as we need to have as much information as possible to do so wisely.

In order to solve some challenges raised in the research, the documentary methodology and field interviews with some market agents were applied.

\section{Having a Look at the Visuals Arts Market}

Economy's growth over the last century and a half has 
allowed the use of resources in areas that were marginal or had not been exploited or discovered. Sports, the latest technology, the space race, music, fashion and the arts in general, are examples.

They represent new forms of business that generate wealth, different from wars or the conquest of territory. This wealth is obtained through the difference between the original value (capital) and a final value that includes the desired utility, an added value that makes a specific activity attractive in a profitable way.

Throughout more than a hundred and fifty years, there have been times of bonanzas and countless economic and financial crisis, which has forced investors to seek new options, safe havens that would allow them to survive, earn higher returns and preserve capital. Preserving capital is an objective of vital importance and is one of the reasons that have led to the rise of emerging markets. Faced with this new reality, the visual arts, as an object of financial investment, have become a singular attraction and a viable business opportunity.

The analysis of this market involves not only financial factors, but also aesthetic factors, so it is essential to have full understanding of these, to assign it appropriate value and price and, as mentioned above, both finance and aesthetics have the same need for accurate and pertinent information.

Since the decade of the 60's, and especially in the 70's, the visual arts became a refuge from the crisis of traditional markets, the oil market, for example. A thriving area of investment appeared, which currently consists of many actors and asset transactions that include different periods and styles of artistic expression throughout the planet.

\section{Visual Arts as an Investment Problem}

Two players activate the sales process with different interests and expectations in the visual arts market: the collector and the investor. Therefore, they must identify the key variables to establish valid criteria that determine and make a profitable investment possible, which is the overall objective of this article. To this end, the following is necessary:

1. Differentiate and conceptualize the reasons for the purchase.

2. Identify key variables according to market participants and their influence.

3. Define the most important features in the visual arts market.

Intention of the purchase.

It is essential to determine the trader's reasons to buy or sell a visual artwork, therefore, it is important to answer these questions:

1. What does art-collecting mean?

2. Who collects art?

3. What does investing in art mean?

4. Who does the investing?

5. Finally, what to buy?

A problem emerges when defining evaluation criteria and the variables involved in the decision making of investing in visual arts. To purchase is not always to invest. We can buy to keep (collect) or to obtain revenue (invest).

Although a collector obtains a social or personal benefit by satisfying more sublime needs than cold hard cash, we cannot consider this value as profit or financial wealth. The personal (or social) satisfaction of sensorial enjoyment cannot be transferred or used to pay for other assets or to meet other needs, since we would be bartering as a means of exchange, a practice that is outside the field of finance and this article. Accordingly, to maintain a position that will represent a portion of our capital, we can have two main intentions:

1. Collecting or,

2. Investing.

De La Poza Plaza, E. expressed the following, regarding this particular:... a piece of art aside from its artistic, historical and cultural appreciation, can also be considered as an economic asset, and therefore as an investment. In fact, in recent years, an important part of society, mainly professionals, invested their surplus or part of them in pieces of art, some as a hobby and others as investment, expecting to obtain a capital gain over a relatively long period. This increases the value of the artistic object over time, considering that one of the features of any art object besides its intrinsic value is being a haven from inflation, able to generate strong capital gains. (P. 27) [5].

Then, collecting visual art means freezing huge amounts of money in order to obtain a personal or social benefit; an individual satisfaction of the senses without monetary compensation. This activity is common to museums, foundations, governments, corporations or individuals with sufficient funds available. On the other hand, to invest in art implies acquiring pieces to be sold at any given time as a way to freeze limited amounts of capital to obtain a real profit in economic and financial terms.

Who does this? Investors: economic entities with enough funds to acquire assets for obtaining a financial return. And again, what to buy? An acquisition will only be considered as an investment because the purpose of this article deals with a financial phenomenon.

\section{Determining Variables to Invest in the Arts Market}

Despite being a complex market with many converging variables, two of them strongly affect and influence the investor: the piece of art itself and the artist. Each of them has particular characteristics, but even so, they are closely related.

\subsection{The Piece}

It represents the finished product of the artist's intellectual and physical effort. It is the actual object being traded on the market, being materialized and allowing its very existence. Without a piece, there is no market for the visual arts. For this reason, the possibility of obtaining new negotiable pieces 
concludes once the artist dies. This fact becomes one of the essential characteristics of the activity represented in a limited supply. From the point of view of the piece of art, this market has clearly defined aspects where you can find a great amount of niches such as painting, sculpture, printmaking, drawing, ceramics, metalwork, lithography, video installation, performance (body art) and net art. In Venezuela, for example, the classification would include pre-Hispanic, colonial, republican, modern and contemporary art. Internationally, this list will surely expand to the Chinese, medieval, Roman, Greek, Renaissance, Gothic, Baroque and Cubist art, among others. Moreover, the Mei Moses Index established nine categories, which includes Impressionist and Modern (IMPMOD), Post War and Contemporary (PWC), Traditional Chinese works of art (TSWA), old master and ninetieth century (OLM19C) American Painting (AMP) and Latin America Painting (LAP), British, Swiss and Italian art [6].

This reveals the variety of the visual arts market, so acquiring a piece with investment intentions becomes complex. When a specific piece is sold for the first time, the transaction is carried out in the primary market, and for subsequent sales the transaction takes place in the secondary one, a kind of second hand market, if the term applies. The latter is the one that encompasses most of the economic activity. Again, De la Poza Plaza, E. offers a clear view on the matter: Within the art market, the primary market corresponds to art galleries or any direct sale performed by the artist, while the secondary market is for auction rooms. Auction houses give the market liquidity, limiting the importance of the galleries. Likewise, they reduce the transaction costs of the pieces in the market by generating lower commissions than those of the art galleries. An important difference between the primary and secondary market is the lack of transparency of galleries, making the secondary market a reliable source of information. (P. 15) [5].

On the other hand, when a piece is highly valued or appreciated among buyers, it is considered as a highly liquid product, because it is easy to sell and buy. An important indicator that emerges from this sales process is the existing relationship between the pieces placed for sale and those actually sold of each artist.

\subsection{The Artist}

He is the producer of the piece, the one that begins the process within the art market. He constitutes one of the two major groups into which, the universe of the arts market has been divided in this study in order to make the analysis easier. It is one of the independent variables in the problem statement, to which the rest of the parameters, explained throughout the present text, are subjected. For this reason, two categories were created: the consecrated and the emerging artist.

Many times the artist and his piece have the same degree of importance, which is why some questions arise such as: which is the piece? The artist or his art piece? What is the underlying asset? What is the buyer acquiring? A few extraordinary strokes on a canvas or a famous artist's signature? The two categories of artists are the following:

\subsubsection{The Acclaimed Artist}

Sale periods get shorter once the renowned artist has an important number of pieces in the secondary market with the costs of promotion and positioning of his artwork covered in the years prior to his success. As a result, the piece is considered a liquid asset, with more lots sold than rejected ones and at much higher prices. Additionally, depending on the segment the artist is in, he can be a leader in his niche, reaching very high profits in shorter periods, which means he has an ascending relationship between sales volume and unit price, generating profits and higher returns than the market average. Jean Michel Basquiat, Andy Warhol, Pablo Picasso, Paul Cezanne, Vincent van Gogh, Salvador Dali and Jesus Soto, are examples of consecrated artists in their respective market niches.

The case of Pablo Picasso and George Braque serves as a basis for defining validation criteria. Both were the founders of Cubism. However, there is a huge difference between them in terms of fame and the price of their pieces. When reviewing both artists' work and careers, we must wonder: What is the added value that Pablo Picasso printed in his pieces that allowed him to achieve higher prices in comparison to George Braque's pieces? Why is the market not willing to pay such figures for a Braque, whereas it does for a Picasso? What made the difference? Quality, technology, age, experience, innovation, better promotion or fashion, location or formats used? How were Pablo Picasso's pieces legitimated and how were George Braque's? Another illustrative example is that of two Venezuelan painters from Valencia, approximately 20 years apart: Oswaldo Vigas and Vladimir Zavaleta. Although they were both winners of the Salon Michelena award, they took different paths. Oswaldo Vigas achieved some international reputation, with significant sales in dollars while Vladimir Zavaleta was practically unknown outside the country but comfortably positioned in the local market with sales in bolivars. Is international exposure key to succeed?

\subsubsection{The Emerging Artist}

It refers to the young artist, not older than 40, with increasing production, some participation in local or regional halls and no significant sales in the secondary market. That is, in great need of promotion since the sale of his pieces require longer exposition time (the time required to achieve maturity) to become a saleable product, starting with low or very low prices, which is known in the media as "workshop prices". In these cases, the investor must wait a longer period to obtain satisfactory earnings. The great ally here is time. The pieces are low liquid (not easily sold), as they are waiting for the market's reaction of either acceptance or rejection of the piece, which would represent the artist's legitimation. In this group, returns can be very large once the artist displays his full potential. At this stage, the artist's qualities, activities and processes must be developed in order 
to evolve into a renowned artist.

As for the factors that contribute to the formation of a classic or acclaimed artist, the 2013 Annual Art Price Report mentions:... The evolution of an artist's market value also depends on many other specific factors from the art world that project the artist, such as the backup of a recognized gallery, the purchase of a piece by a renowned collector, the achievement of a certain price level or the announcement of an exhibition at a major institution. As a rule, the more an artist is known, the more expensive his artwork becomes. The same way information flows quickly, contemporary art is subjected to the effects of fashion, so buyers tend to purchase the same things. The turning points of an artist's market value are reflected on his curriculum vitae and the age factor is obviously taken into account.

The classics in contemporary art are those that already have reputation and have been exhibited at art galleries for fifteen, twenty or thirty years. Their presence in large sales catalogs becomes an event not to be missed since their pieces are coveted trophies and the incomes they generate, a blessing for auction houses. Jeff Koons, Takashi Murakami, Damien Hirst, Cindy Sherman and Jean-Michel Basquiat are included in this group. Currently, their prices challenge those of ancient, impressionist and modern masters. (P. 29) [7]. Additionally, regarding young and emerging artists Artprice comments: The market value stages are registered in younger artists' curriculum vitae and the age factor is obviously important. However, the races for novelty, speculation and the accelerating pace of auctions have altered market rules.
Since the nineties, the art market has assimilated novice artists (sometimes in their early twenties) at a fast growing rate provided they have the right pedigree and manage to raise their prices fast, up to $100 \%$ or $200 \%$, sometimes after two or three years. (P. 29) [7].

On the issue of promotion and past performance of an emerging artist as a decision factor, the example Halim Badawi shows is useful. He says: Last June 26, Christie's auction house (London) auctioned a piece by Colombian artist Oscar Murillo for $\$ 391$ thousand or 756 million pesos. With this magical marketing exercise, Murillo, only 28 years old, became one of the five most expensive Colombian artists, outrivaling Alejandro Obregón, Andrés de Santa María and Alipio Jaramillo, and placing the price of one of his pieces at the same level of Fernando Botero and Doris Salcedo, who are renowned artists. For many in the art world, Murillo is a stranger. Indeed, he is. His work is not in permanent or temporary exhibitions at any museum, there are no papers on his work and very few have heard his name in Colombia [8].

By choosing a piece from an emerging artist as an investment, the asset should become legitimate, recognized and approved over time by the art market, defining its path to become renowned. This process will permit the collection of the expected utility. On the other hand, if the emerging artist does not get legitimization, recognition or approval, he will become a master and the earnings of the initial investment will not meet expectations. Figure 1 shows the trajectory and evolution of an emerging artist.

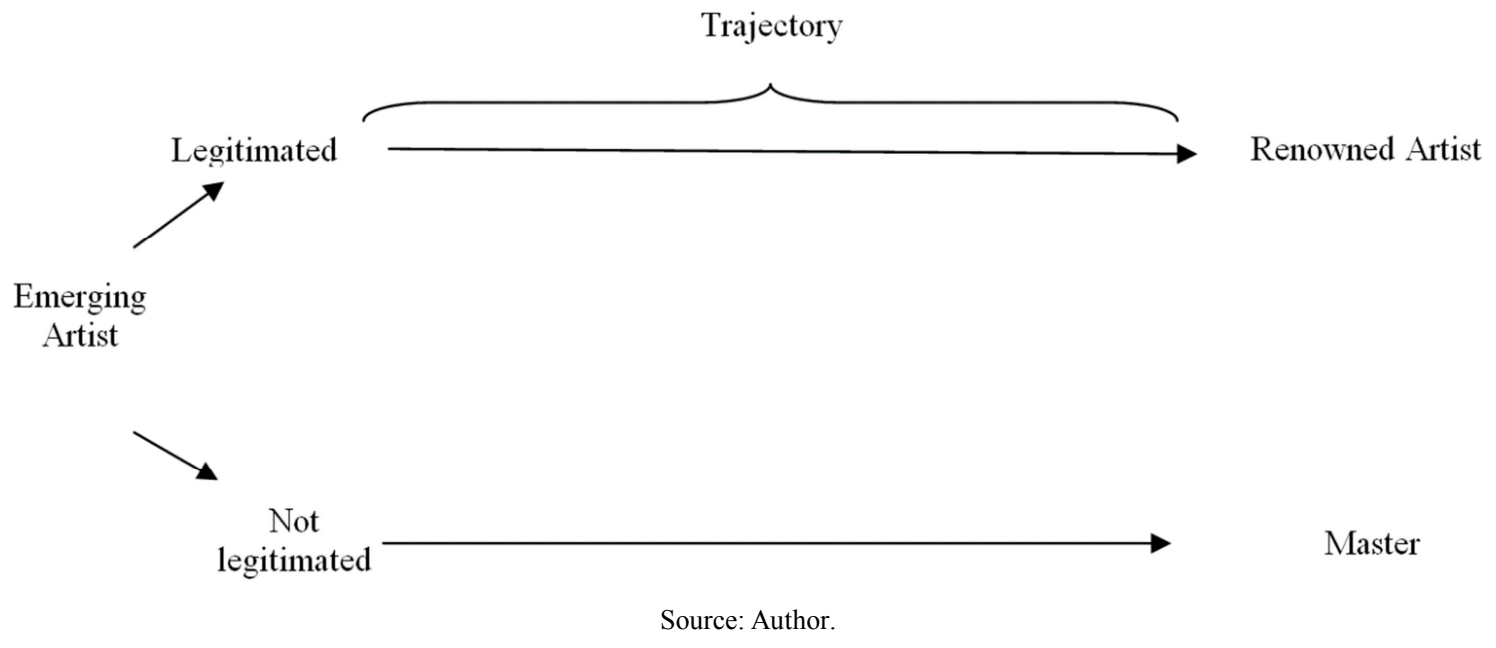

Figure 1. Trajectory of the emerging artist.

\section{Evaluation Criteria}

To establish valid investment criteria as to obtain reasonable profit, it is necessary to evaluate the artist, his career and his artwork. These parameters are grouped into four different categories, but they are all related:

1. Those attributed to the artist.

2. Those attributed to the piece.

3. Those inherent to the market (either primary or secondary).
4. Those of the investor.

The above classification enables the analysis and structure for a decision-making guide. It is important to note that some parameters or attributes can converge into two or more categories.

\subsection{Criteria Attributed to the Artist}

\subsubsection{Age}

An artist generally achieves recognition once he has reached a middle or advanced age although there are 
exceptions such as Jean Michel Basquiat.

\subsubsection{Experience}

Whether the artist has exhibited in galleries or sold pieces for significant amounts of money, his career in general must be assessed.

\subsubsection{Death}

This event has a sensible impact on the price of the visual art piece, perhaps because it increases the quality of being something unique and unrepeatable due to the permanent absence of the producer of the asset.

\subsubsection{Style}

Still lifes, impressionism and surrealism; prices depend on market requirements. An ambitious artist will keep an eye on the market and be alert for trends in demand.

\subsubsection{Location}

An artist, and therefore his work, can have local, regional, national, international or universal importance. The place where the artist has developed his work influences the price as well.

\subsection{Criteria Attributed to the Piece}

\subsubsection{Single Piece}

This parameter gives the piece its quality of being rare, scarce and unrepeatable so these conditions affect the price. When the asset lacks such attributes, the price will most likely drop.

\subsubsection{Conservation}

A piece of art in perfect conditions will have a higher price and more marketing possibilities compared to others in need of restoration and maintenance.

\subsubsection{Price}

The importance of the price is that through it, we get the expected return of the investment.

\subsubsection{Style}

This is one of the parameters that can be found in different categories. In this case, its nature is the same as that of the plastic artist category.

\subsubsection{Authenticity}

It represents the link between the piece and the artist. It is the signature, certificate of authenticity or an expert's opinion through a technical study. Only authentic, unique pieces are priced and sold therefore the market must ensure this quality to avoid frauds.

\subsubsection{Format}

The size of the piece affects the price. The public has consistently shown a preference for formats of 1 sq. $\mathrm{m}$ on average to purchase.

\subsubsection{Location}

The geographic location, a suitable environment to protect and preserve the piece affects the price and its possible future sale. Also, the importance of the piece influences the possibility of exporting it or not, a fact that restricts its commercialization. For example, after a piece becomes a national heritage in Spain, it cannot leave the country without official permission. Location also enables a piece to be moved, making it more or less saleable. The Last Supper by Leonardo Da Vinci, for example, would be more difficult to sell than the Mona Lisa from the same author, in the hypothetical event that they could be purchased.

\subsection{Criteria Inherent to the Market}

\subsubsection{Primary Market}

When an artist sells his piece for the first time, to either a gallery or a dealer.

\subsubsection{Secondary Market}

When the piece is sold in galleries by art dealers or any other distribution channel and the artist no longer holds the property. Figure 2 shows both markets.

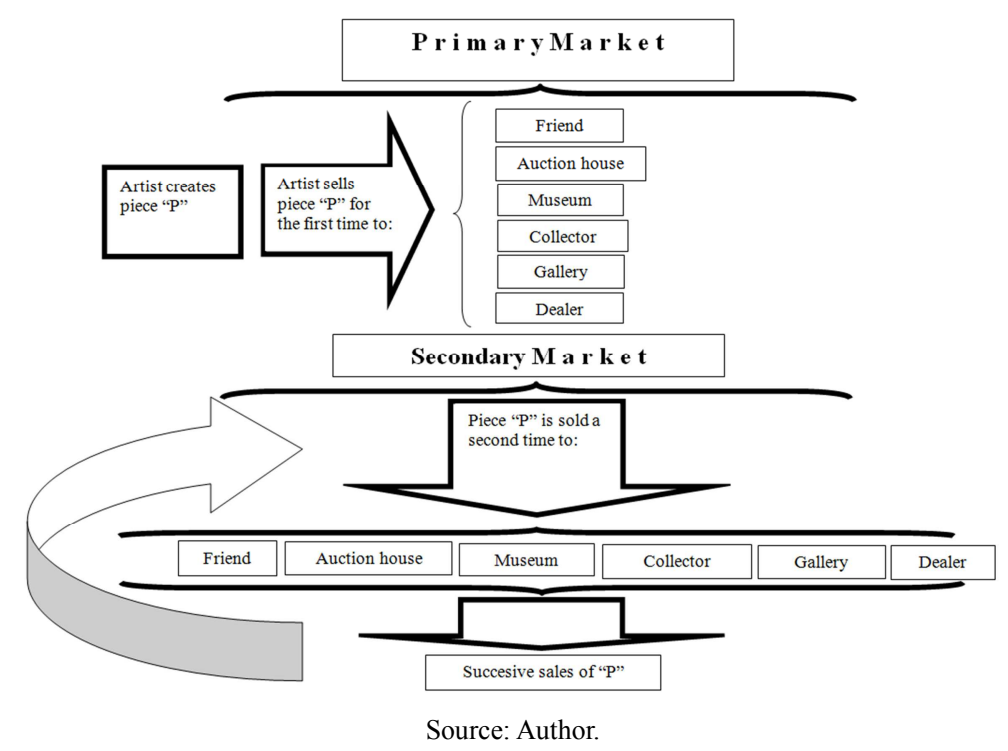

Figure 2. Primary and secondary market. 


\subsubsection{Auction}

It is the sale of an art piece to the highest bidder. In the art market, those pieces sold at Sotheby's or Christie's, have a better market price than those sold in less formal markets. This is because of the guarantee of authenticity that these companies grant the asset, giving the author legitimacy, prestige and a better reputation. It is an organized and formal market that dominates the largest number of transactions worldwide and covers the broadest spectrum of supply and demand for pieces of art, not only paintings but also other genres such as antiques. Aspects such as legal origin, authorship or authentication certificates, insurance, custody, transports, commissions and taxes are important elements in transactions within this business model and help minimize transaction risks. It is a secondary market, similar to a stock exchange. In this case, art stock. Due to their high specialization, they act as a cartelized group that sets the price of the piece and therefore, the artist's image.

\subsubsection{Art Dealer}

$\mathrm{He}$ is an independent negotiator of art pieces and an important element in the market of visual arts. An artist concerned for his career should have a good art dealer as a consultant.

\subsubsection{Informal Market}

The one that lacks rules and regulations with legal foundation. It is a less structured market where art pieces are traded without legal rigidities, but still considering the origin and authenticity of the asset. It mostly operates locally among small groups with few participants, often only buyer and seller. Sales can be carried out in local or foreign currency, but legal formality is nonexistent or not always appropriate.

\subsubsection{Black Market}

It is where famous pieces are traded. They are usually stolen or their origin questionable. It is of high-risk due to the frequency of fakes and forgeries of signatures and author names.

\subsubsection{Price}

The parameter defines the price of the art piece on the market. It represents the value the vendor is willing to accept to deliver the asset and the buyer to purchase it, thus carrying out the purchase agreement and materializing two interests: the aesthetic need and financial profit.

\subsubsection{Liquidity}

The capacity of the art piece to be sold in successive transactions and how fast (short waiting times) it is done.

\subsubsection{Market Site}

London, New York, Miami, Beijing and Caracas.

\subsubsection{Speculation}

Like any market, the arts market is susceptible to manipulations, allowing the profit due to changes in the variables involved. An example of this are the financial bubbles, or real estate bubbles and, of course, the bubbles in the market for the visual arts.

\subsection{Bubbles in the Art Market}

In terms of money, a bubble takes place when the price of any financial instrument increases its real value too fast and excessively for a relatively long time with no apparent logical reason. This lasts until, due to market forces, "the bubble bursts" and the price falls to very low levels, causing losses and economic crisis. Often "the causes for the bubble" are purely speculative. A sample of a bubble in contemporary art can be seen in the Chinese market, which, according to ArtPrice (P. 13) slowed sharply in 2012 due to the cooling of world economy, liquidity problems, inflated prices that affected the market and the reduction of funds and participations from speculative investments, which caused that most of the offered lots remained unsold [7].

For example, according to Sophie Song the disproportionate increase in sales of Chinese plastic artist Zhang Daqian's pieces (May 10, 1899 - 2 of April 1983), which reached $\$ 506.7$ MM, considerably surpassing painters such as Pablo Picasso, with sales of \$360 MM in the same period, suggests possible price manipulation [9]. In addition, auctions are another source of market disruption, providing loans to buyers or manipulating the prices by bidding for their own lots, as described in the statements made by art critic Jason Edward Kaufman in El Universal. He states: But what is the role of auctions in this apparent bubble? While it is estimated that higher prices are reached in private sales, - the most expensive painting ever sold is believed to be "The Card Players" by Cézanne, acquired by the Royal House of Qatar between $\$ 250$ and \$300 million (185 and 222 million Euros) - auctions have a different function [10].

In an unregulated market, auctions are the only public appraisal of art. Aware of this function, cheating is inevitable. "If the owners of a painting want it to have a public value, they can agree to buy it for a high price to revalue the pieces they still possess."

Once this situation is corrected, a loss in the investment is expected to occur because no market participant will be willing to pay hefty values for a piece by a national artist.

\section{Investor Criteria}

\subsection{Capital Limitations}

No funds are infinite, forcing the investor to efficiently distribute the money available. This is a strong limiting factor when purchasing a piece of art.

\subsection{Profitability Expectations}

The return expected by the investor over a period. 


\subsection{At the Auctions}

The frenzy when bidding.

\subsection{Aversion to Risk (Higher or Lower)}

The investor's tendency to take risks. This factor varies from one person to another and limits the investment.

\subsection{Knowledge of the Art Market (Expertise)}

In the same proportion that the investor knows the art market, he will be successful at accumulating wealth through the acquisition of a piece of visual art.

\subsection{Low Degree of Correlation}

Within an art investment portfolio. For instance, if you own a Picasso, a Degas and a Soto, there will be different reasons as to why the prices of each of these pieces of art remain. That is, if for any reason the Picasso price drops, this should not necessarily affect the price of the other two pieces, thus diversifying the investment risk. It would be ideal to diversify, investing in market assets of a different nature to balance the portfolio. Figure 3 shows a summary of these investment criteria.

\section{Decision Making Criteria}

\section{Trajectory}

Emerging Artist

Or

Renowned Artist

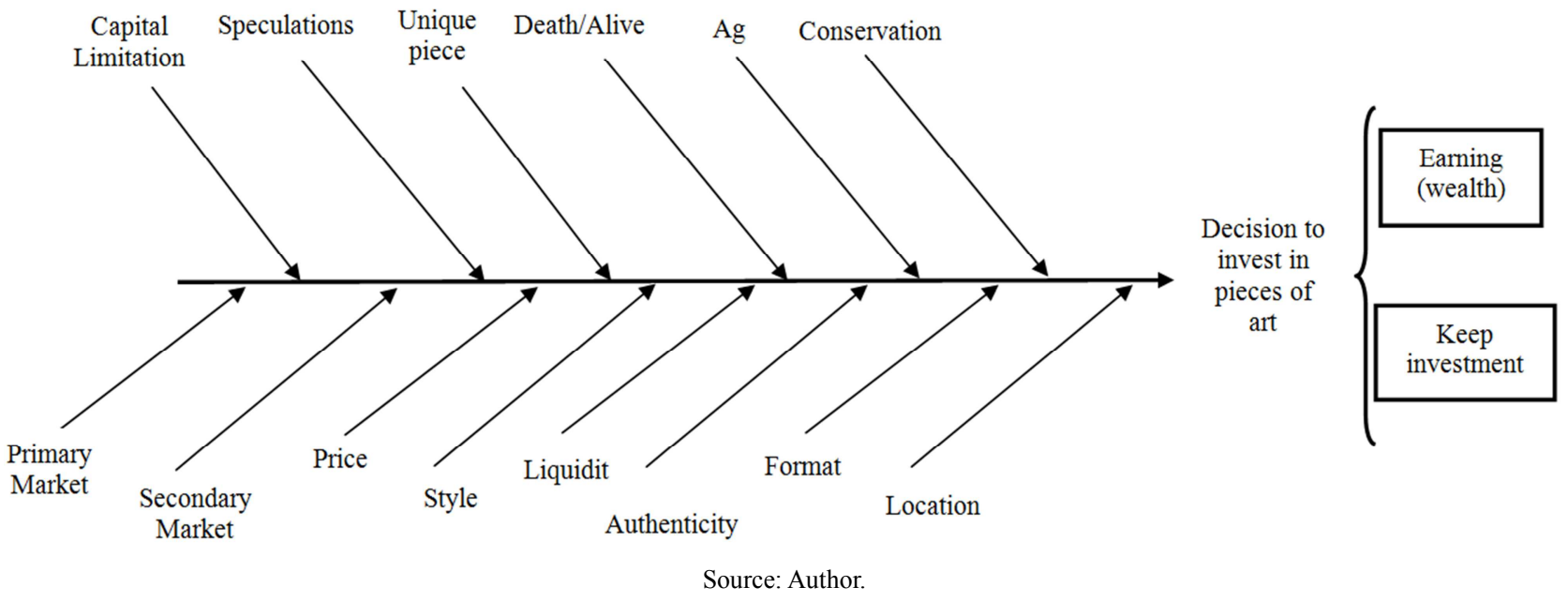

Figure 3. Summary of Decision Making Criteria.

\section{Who Is the Investor}

The one who acquires pieces of art to obtain a financial advantage in a given period. That is, the one who buys and sells, exposing the capital intended for that purpose to the risks inherent to the transaction. Hence, the investor should consider some principles or rules.

Investor Principles

1. Be prudent.

2. Consult with an expert valuator to ensure the market price.

3. Know the difference between a piece that is a national heritage and one that is simply an asset (piece of art) that can be bought and sold.

4. Consider possible price components: quality, psychological and market factors, crises in other sectors and think about the art sector a refuge.

\section{Features of the Market for the Visual Arts}

Some of the most important characteristics of this market are:

It is a small market, not deep. For instance, if we compare agents of the art market to the banking area, according to Nasdaq for the closing as of September 30, 2014, Sotheby's auction house presented an income of $\$ 587$ million (from all of its departments), while Bank of America (2014) showed an income of 2 billion 249 dollars (and just in the global banking segment) [11].

Additionally, with the idea of comparing the performance of the same agents in both markets, from Yahoo Finance (a). [12] and Yahoo Finance (b). [13], table 1 is presented as follows: 
Table 1. Sotheby's Vs BOFA 2017.

\begin{tabular}{lll}
\hline & Total Revenue & Net Income \\
\hline BOFA & $83,956,000$ & $18,232,000$ \\
Sotheby's & 989,389 & 118,796 \\
Sotheby's/BOFA \% & $1.18 \%$ & $0.65 \%$ \\
\hline
\end{tabular}

Highly specialized.

It is segmented.

There are few participants, suppliers and buyers.

The object of negotiation (the piece of art) has deep subjective conditions that determine its trading price, therefore, its value in the market.

The object of trading is scarce and unrepeatable, conditions that affect the price directly. That is, they are not standardized units issued in large quantities, for example, national debt or oil production.

They are not intended for massive consumption.

Sometimes, especially in the pricing, the producer or manufacturer (the artist) and the product (the piece of art) are equally important. Such is the case of Pablo Picasso, his signature and the work itself.

The art market behaves like a monopoly when it comes to offers since there are few producers or artists with limited pieces and many buyers, investors and collectors.

It is necessary to define the added value a piece has as a product. In other words, what needs does it meet?

\subsection{Art Market Participants}

When studying the capital market, we usually use a common phrase: market and financial institutions. Every place where buyers and sellers come together to exchange goods and services is a market, and it does not necessarily refer to a physical location. Other economic agents, institutions, regulations, transactions, prices and trends are also involved. The same happens in the visual arts. In the present case, other aspects involved are: a) auction houses, b) galleries, c) curators, d) commissioners, e) dealers, f) conservationists, g) fairs, h) patrons, i) agents, j) art critics, $k$ ) government, 1) regulating laws, m) the public. Each of them, and all together, make up the site (physical or not) where artworks are bought and sold, regardless of the intention. Each and every one of them influence and affect the market.

\subsection{Economic, Financial and Accounting Aspects of the Art Market}

Like any object under market forces, a piece of art involves economic, financial, tax and accounting issues.

From a financial and accounting point of view, the art pieces are non-monetary assets, protected from inflation, that is, their value increases and thus avoids the erosion of the capital of the investor or collector.

Therefore, they provide a haven in times when the purchasing power of currency deteriorates, depending on the economic tendency, according to Deloitte and Artactic (P. 42) [14].

They are affected by financial events, such as the bubble effect.
Low degree of correlation within an art investment portfolio.

In Venezuela, under the Law of Income Tax, Article 173, second paragraph, the updating of the acquisition cost is allowed with reference to inflation [15].

According to the provisions of the Law of Added Value, Article 4, paragraph 2, art pieces are liable to be taxed with AVT since they are movable assets [16].

Considering they are economic objects, it is difficult to determine the reasons by which they add value to the economy and the needs they meet. That is to say, why would a painting by Pablo Picasso be worth 104 million Euros and another by the same author worth 60 million?

\section{Conclusions}

Due to the complexity of the Art Market as an economic activity, many variables must be defined and controlled. In the first place, the purpose of the artwork must be determined, that is, if it will be to invest or to collect, for which it is convenient to have adequate information and plenty of capital without restrictions.

At present, the most attractive market is that of Contemporary Art, being the most important centers New York and London, with China (Hong Kong and Beijing) as an emerging market. They represent the highest international level, including the Venezuelan market, since there are limitations and restrictions in the segments of great masters and the classics. That is why emerging artists and their work must ascend during their career, from the local to an international level in order to become renowned within their discipline. If an artist dies without having ascended to a higher level, the risk of loss for the buyer increases since it will be very difficult for the artist to receive recognition later, unless there is a bubble effect or a special event as in the case of Vincent Van Gogh.

An important finding was to ascertain the huge difference within an artist's career between being "local" in Paris and being "local" in Valencia, Venezuela. This establishes a relationship between the chronological evolution of the plastic artist and his market price. Except for having restricted capital, the prediction or commitment to invest in an emerging artist is more uncertain than doing so in a consecrated artist.

Finally, it was determined that there are countless variables and parameters within the art market that have not been studied and that affect price and investment.

\section{Acknowledgements}

I would like to thank the help of Felix Suazo and Nancy Farfán. Their knowledge of the contemporary art market was very valuable and served as a basis to complete this article. Likewise, I wish to thank Adda Morales for her help in the translation of this text. 


\section{References}

[1] Sherman A and Morrissey C. What Is Art Good for? The Socio-Epistemic Value of Art. Front. Hum. Neurosci. 11: 411. doi: 10.3389/fnhum.2017.00411. 2017.

[2] Artprice. Informe anual. Coleccionar e invertir en arte. 2017. Retrieved from https://www.artprice.com/artprice-reports/theart-market-in-2017/collecting-and-investing-in-art/.

[3] Artsgain. Art Investment Informative Leaflet. 2018. Retrieved from https://www.artsgain.com/wpcontent/uploads/2017/12/Art-Investment-Leaflet-v4.pdf.

[4] Securities and Exchange Commission. Sotheby's annual report. 2017. Retrieved from https://sothebys.gcsweb.com/static-files/3c843441-89db-4556-924afcbd6639c74b.

[5] De la Poza Plaza, E. Los activos del mercado del arte como objeto de inversión financiera (Tesis doctoral, Universidad Politécnica de Valencia, España. 2008. Retrieved from http://www.upv.es/pls/soarc/sal_doc_deptesis.Veradj?p_nreg= 2818\&P_VISTA=\&P_IDIOMĀ=c.

[6] Mei, Jianping; Moses, Michael. The Mei Moses Fine Art Index. 2014 Retrieved from http://www.artasanasset.com/main/artinvesting.php.

[7] Artprice. El mercado del arte Contemporáneo. Informe anual Art Price 2013. Lyon. Retrieved from http://imgpublic.artprice.com/pdf/artprice-contemporary2012-2013-es.pdf.

[8] Badawi, Halim. Business is business: especulación y mercado en la obra de Óscar Murillo. Esfera Pública.2013. Retrieved from http://esferapublica.org/nfblog/?p=62949.

[9] Song, Sophie. Chinese Painter Zhang Daqian's Works Earned More Than $\$ 500$ Million In 2011, More Than Works By Pablo Picasso. 2013. Retrieved from http://www.ibtimes.com/chinese-painter-zhang-daqiansworks-earned-more-500-million-2011-more-works-pablopicasso-12863433.
[10] El Universal. Una burbuja con mucho arte. Entrevista a Jason Edward Kaufman. Agencia EFE. Nueva York. 2013. Retrieved from http://www.eluniversal.com/arte-yentretenimiento/131116/una-burbuja-con-mucho-arte.

[11] Nasdaq Globe Newswire. Sotheby's Reports First Nine Months 2014 Financial Results. 2014. Retrieved from http://globenewswire.com/news-

release/2014/11/10/681588/10107251/en/Sotheby-s-Reports-

First-Nine-Months-2014-Financial-Results.html\#sthash.GulVo rlS.dpu.

[12] Yahoo Finance (a). Bank of America Financial Statemts 2017. 2019Retrieved https://finance.yahoo.com/quote/BAC/financials?p=BAC.

[13] Yahoo Finance (b). Sotheby's Financial Statemts 2017. 2019. Retrieved from https://finance.yahoo.com/quote/BID/financials?p=BID.

[14] Deloitte and Artactic. Art \& Finance Report 2013. 2014. Retrieved from http://www2.deloitte.com/lu/en/pages/artfinance/articles/art-financereport.htmlhttp://web.artprice.com/artmarketinsight/759/+Lati $\mathrm{n}+$ American+Contempora ry+artists? $1=\mathrm{en}$.

[15] Ley del Impuesto Sobre la Renta. Gaceta oficial de la Republica Bolivariana de Venezuela número 38628 del 16 de febrero de 2007. Retrieved from http://declaraciones.seniat.gob.ve/portal/page/portal/MANEJA DOR CONTENIDO SENIAT/02NORMATIVA LEGAL/2.4 TRIBUTOS_INTERN̄OS/2.4.02ISLR/2.4.2.html.

[16] Ley del Impuesto al Valor Agregado. Gaceta oficial de la Republica Bolivariana de Venezuela número 38632 del 26 de febrero de 2007. Retrieved from http://declaraciones.seniat.gob.ve/portal/page/portal/MANEJA DOR_CONTENIDO_SENIAT/02NORMATIVA_LEGAL/2.4 TRIBUTOS_INTERNOS/2.4.03IVA/2.4.3.html. 